\title{
Is multi-drugs resistant Acinetobacter baumannii epidemic spread related to reduced susceptibility to biocides?
}

\author{
B Casini ${ }^{1,2^{*}}$, MG Minacori ${ }^{1}$, A Buzzigoli ${ }^{1}$, P Valentini ${ }^{1,2}$, P Morici ${ }^{1}$, S Barnini ${ }^{3}$, C Tascini ${ }^{4}$, F Menichetti $^{4}$, GM Rossolini ${ }^{5}$, \\ G Privitera $^{1,2}$
}

From International Conference on Prevention \& Infection Control (ICPIC 2011)

Geneva, Switzerland. 29 June - 2 July 2011

\section{Introduction / objectives}

Aim of this study was to assess the role of active extrusion in mediating decreased susceptibility to biocides in the persistance and spread of multi-drugs resistant of $A$. baumannii strains isolated in intensive care units of a tertiary-care teaching hospital.

\section{Methods}

67 clinical and 24 environmental strains isolated from 2007 to 2010 were genotyped by PFGE, MLST and REP-PCR. Multiplex PCRs were performed for identification of the ompA, csuE and bla $a_{\mathrm{OXA}-51 \text { like }}$ sequence type groups. The antimicrobial susceptibility was determined and the presence of carbapenemase-encoding genes was analysed by characterization of the bla $\mathrm{OxA}_{\mathrm{A}}$ genes. Chlorine susceptibility was analysed according to BS EN 1040:1997

\section{Results}

The cross-analysis of genotyping methods allowed to group strains into 4 clones, only the clone A belonging to the Group 1 corrisponding to European II clonal complex and the clone B belonging to Group 2 clonal complex European I. Since 2008, a new variant of clone A has emerged as the predominant clinical and environmental strain, resulting positive for the presence of the carbapenemase OXA-58 plasmid-mediated and showing reduced chlorine susceptibility in vitro

\section{Conclusion}

Multi-antibiotic resistance may not be the only strategy applied by $A$. baumannii to spread and persist in healthcare setting, but also the increased resistance to biocides

\section{Disclosure of interest}

None declared.

\section{Author details}

${ }^{1}$ Dep. Experimental Pathology, MBIE, University of Pisa, Pisa, Italy. ${ }^{2}$ U.O. Igiene ed Epidemiologia, Azienda Ospedaliero-Universitaria Pisana, Pisa, Italy. ${ }^{3}$ U.O. Microbiologia, Azienda Ospedaliero-Universitaria Pisana, Pisa, Italy. ${ }^{4} U$.O. Malattie Infettive, Azienda Ospedaliero-Universitaria Pisana, Pisa, Italy. ${ }^{5}$ Dep. Molecular Biology, University of Siena, Siena, Italy.

Published: 29 June 2011

doi:10.1186/1753-6561-5-S6-P300

Cite this article as: Casini et al:: Is multi-drugs resistant Acinetobacter baumannii epidemic spread related to reduced susceptibility to biocides? BMC Proceedings 2011 5(Suppl 6):P300.

Submit your next manuscript to BioMed Central and take full advantage of:

- Convenient online submission

- Thorough peer review

- No space constraints or color figure charges

- Immediate publication on acceptance

- Inclusion in PubMed, CAS, Scopus and Google Scholar

- Research which is freely available for redistribution

Submit your manuscript at www.biomedcentral.com/submit 